\title{
Fishing down a Caribbean food web relaxes trophic cascades
}

\author{
Peter J. Mumby ${ }^{1, *}$, Robert S. Steneck ${ }^{2}$, Alasdair J. Edwards ${ }^{3}$, Renata Ferrari ${ }^{1}$, \\ Robin Coleman ${ }^{4}$, Alastair R. Harborne ${ }^{1,5}$, Janet P. Gibson ${ }^{4}$ \\ ${ }^{1}$ Marine Spatial Ecology Lab, School of Biological Sciences \& ARC Centre of Excellence for Coral Reef Studies, \\ Goddard Building, University of Queensland, St. Lucia Campus, Brisbane, Queensland 4072, Australia \\ ${ }^{2}$ School of Marine Sciences, University of Maine, Darling Marine Center, Walpole, Maine 04573, USA \\ ${ }^{3}$ School of Biology, Newcastle University, Ridley Bldg, Newcastle upon Tyne NE1 7RU, UK \\ ${ }^{4}$ Wildlife Conservation Society, PO Box 768, 1755 Coney Drive, 2nd Floor, Belize City, Belize \\ ${ }^{5}$ Marine Spatial Ecology Lab, College of Life and Environmental Sciences, University of Exeter, Exeter EX4 4PS, UK
}

\begin{abstract}
The fishing down of marine food webs has been described in pelagic and demersal systems but rarely documented in coral reef environments. We recorded a rapid shift in fish community structure in Belize that accompanied a marked decline in grouper and snapper abundance and a switch towards smaller, less desirable, herbivorous parrotfishes. In a 6 to 7 yr period (2002-2008/09), observations of large-bodied grouper (Serranidae) declined significantly from an encounter probability of $21 \%$ per $200 \mathrm{~m}^{2}$ transect to just $2 \%$. The biomass of carnivorous snappers (Lutjanidae) underwent a 7 -fold decline, primarily in the species Ocyurus chrysurus. During this period, the inclusion of parrotfish in fish catches at nearby Glover's Atoll increased from a frequency of $6 \%$ in 2004 to $\sim 20 \%$ of speared individuals by 2008. Parrotfish biomass declined by $41 \%$ between 2002 and 2008/09, with a major decline in the large and dominant herbivore Sparisoma viride. No changes in parrotfish biomass were detectable in nearby marine reserves during this time. Several important indirect effects of fishing were observed. The biomass of mesopredators including Cephalopholis fulvus, C. cruentatus, and Epinephelus guttatus increased dramatically by $880 \%$ as compared to the 2002 levels. We putatively attribute this response to a release from predation and constraints to foraging behaviour imposed by large serranids. Further, we find that the density of adult damselfish of the species Stegastes planifrons and S. partitus decreased by $\sim 45 \%$. We attribute this decline to elevated predation by the increased densities of mesopredators, which have been shown to prey upon juvenile damselfish. No change in damselfish densities was found at 2 control locations where fishing was prohibited. The decline in parrotfish in the central Mesoamerican barrier reef likely accounts for recent anecdotal observations of Halimeda tuna spreading to microhabitats that have previously been grazed intensively. While these results imply that the resilience of these reefs may be seriously impaired, the Belize Government has recently enacted new legislation to improve the management of grouper and outlaw harvesting of most herbivorous fish.
\end{abstract}

KEY WORDS: Fishing · Coral reef · Parrotfish $\cdot$ Grouper $\cdot$ Snapper $\cdot$ Damselfish $\cdot$ Trophic cascade Resale or republication not permitted without written consent of the publisher

\section{INTRODUCTION}

The phenomenon of 'fishing down marine food webs' (Pauly et al. 1998) is well established in both pelagic and demersal finfish fisheries. Species at higher trophic levels, such as large piscivores, are depleted first. As they become rare, the fishery progressively depletes species at lower trophic levels over time. Exploitation of successively lower trophic groups can occur for 2 reasons, and both apply to 
many fisheries. The life history traits of species at high trophic levels, such as gaining maturity at a relatively large body size and late age, render their populations highly vulnerable to fishing mortality (reviewed in Jennings \& Kaiser 1998, Cheung et al. 2007). Species at high trophic levels may also be preferentially targeted because of high consumer demand (McManus 1997, Coleman et al. 2000). This is particularly true of many coral reef systems where large groupers (Serranidae) are preferentially targeted (Russ 1991, Sadovy 2005).

Despite the great cultural and economic role of fishing in coral reef environments, there have been few documented cases of 'fishing down coral reef food webs'. The paucity of such studies largely reflects the long history of fish exploitation (Jackson et al. 2001) such that many systems had already been heavily depleted by the time that reef fish monitoring emerged in the 1960s. Some important exceptions exist including detailed accounts of fish responses to the opening and closure of fisheries in the Philippines (Russ \& Alcala 1998b), long time-series of data from the US Virgin Islands (Friedlander \& Beets 2008) and the Florida Keys (Ault et al. 1998), and a comparison of fish communities in Jamaica over a relatively long time interval from 1969 to 1986 (Koslow et al. 1988). Nonetheless, much more is known about the recovery of fish after the establishment of no-take reserves (Roberts 1995, Russ \& Alcala 1998a, McClanahan \& Graham 2005), than the rates of declining species abundance during an active fishery.

Given the difficulty of following the fate of a fishery over time, many important insights into the effects of harvesting on fish communities have compared fish communities along a gradient of human impact (Jennings \& Polunin 1995, Friedlander \& DeMartini 2002, Newman et al. 2006, Harborne et al. 2008). Of particular ecological interest is whether human activities cause cascading impacts on community structure over at least 3 trophic levels (Pinnegar et al. 2000, Micheli et al. 2004, Estes et al. 2011). However, detecting trophic cascades, or even evidence of a single trophic interaction such as the release of prey when a predator is depleted, is a formidable challenge, in part because of the plethora of factors that influence species' abundance (Steneck 1998).

It would be difficult to identify any truly global expectations for trophic cascades on coral reefs. Although relevant studies have been carried out in all 3 tropical oceans, differences in species diversity, species identity, local environmental conditions, and the intensity of exploitation all potentially confound syntheses of multiple studies. Perhaps the most re- peatable observation to date is a general lack of support for numerical increases in prey species once their piscivore predators have been heavily depleted by fishing. Examples of weak or undetectable relationships stem from Hawaii (Friedlander \& DeMartini 2002), the Seychelles (Jennings et al. 1995), Fiji (Jennings \& Polunin 1997), the Bahamas (Mumby et al. 2006), the Philippines (Russ 1985), and the Pacific Line Islands (Sandin et al. 2008).

Here, we describe the remarkable change in fish communities that occurred after a 7 yr period of fishing in Belize, Central America (2002-2008/09). The low human population density of Belize (13 people $\mathrm{km}^{-2}$ ), together with the large size of its barrier reef system ( 250 km in length), has meant that reefs were considered to be relatively lightly fished compared to many other parts of the Caribbean (Hay 1984, Pandolfi et al. 2003). Indeed, at the start of the study (2002) the fishery for finfish focused mostly on lutjanids and serranids (Koslow et al. 1994, Paz \& Truly 2007) and the exploitation of herbivorous parrotfishes was uncommon and confined to subsistence uses. However, our study captures a critical change in the fishery during which larger, desirable species underwent a marked decline and fishers literally began fishing down the food chain. We document the changes that have occurred in the fish communities over time and provide correlative evidence of trophic cascades, which imply that some important prey species can exhibit a numerical increase once released from predation. In our case, the trophic cascade is tritrophic involving large predators (large-bodied grouper), mesopredators (small-bodied groupers), and damselfishes (Pomacentridae). Thus, our study describes the striking changes in fish communities that can occur through direct and indirect effects of fishing over a short, 7 yr period during which a priority fish group, grouper, became scarce, prompting a switch in target species.

\section{MATERIALS AND METHODS}

\section{Study sites and census dates}

The majority of this study was carried out within the boundaries of the South Water Caye Marine Reserve (hereafter simply referred to as South Water Caye). The reserve was officially announced in 1996 but the fully protected area or Conservation Zones were not fully established until 2009. South Water Caye lies in the central part of the Belize Barrier Reef and 6 sites were located on the outer forereef at a 
depth of 10 to $13 \mathrm{~m}$, and ranged from Tobacco Reef in the north to $5 \mathrm{~km}$ south of South Water Caye itself (Fig. 1). While all sites at South Water Caye lie within reserve boundaries, our sampling pre-dates the cessation of fishing at sites within the reserve, and therefore our data from South Water Caye can be thought of as representing the effects of continued fishing. To contrast the effects of fishing, 2 additional sites (C1 and C2) were located at Glover's Reef, which is an offshore atoll located directly east of South Water Caye. A marine reserve has been enforced on parts of Glover's Reef since 1996 and parrotfish community structure has been monitored since 1998 at 2 comparable windward forereef sites to those found at South
Water Caye (Mumby et al. 2005). Both sites at Glover's were located in the reserve, which is enforced. Fisheries catch outside the boundaries of the reserve at Glover's has been sampled since 2004 and these data were used to provide a context for the fishery at our prime study sites at South Water Caye.

Fishing impacts were determined using a binary approach that distinguished the study 'start' in June 2002 and 'end' in 2008/09. Surveys of study 'end' were taken over a period of $\sim 1 \mathrm{yr}$, from March 2008 to March 2009 (Table 1), and all surveys were undertaken within $5 \mathrm{~d}$ of new moon. While the actual sampling interval varied from 6 to $7 \mathrm{yr}$, we did not attempt to distinguish the status of reefs after 6 versus $7 \mathrm{yr}$.

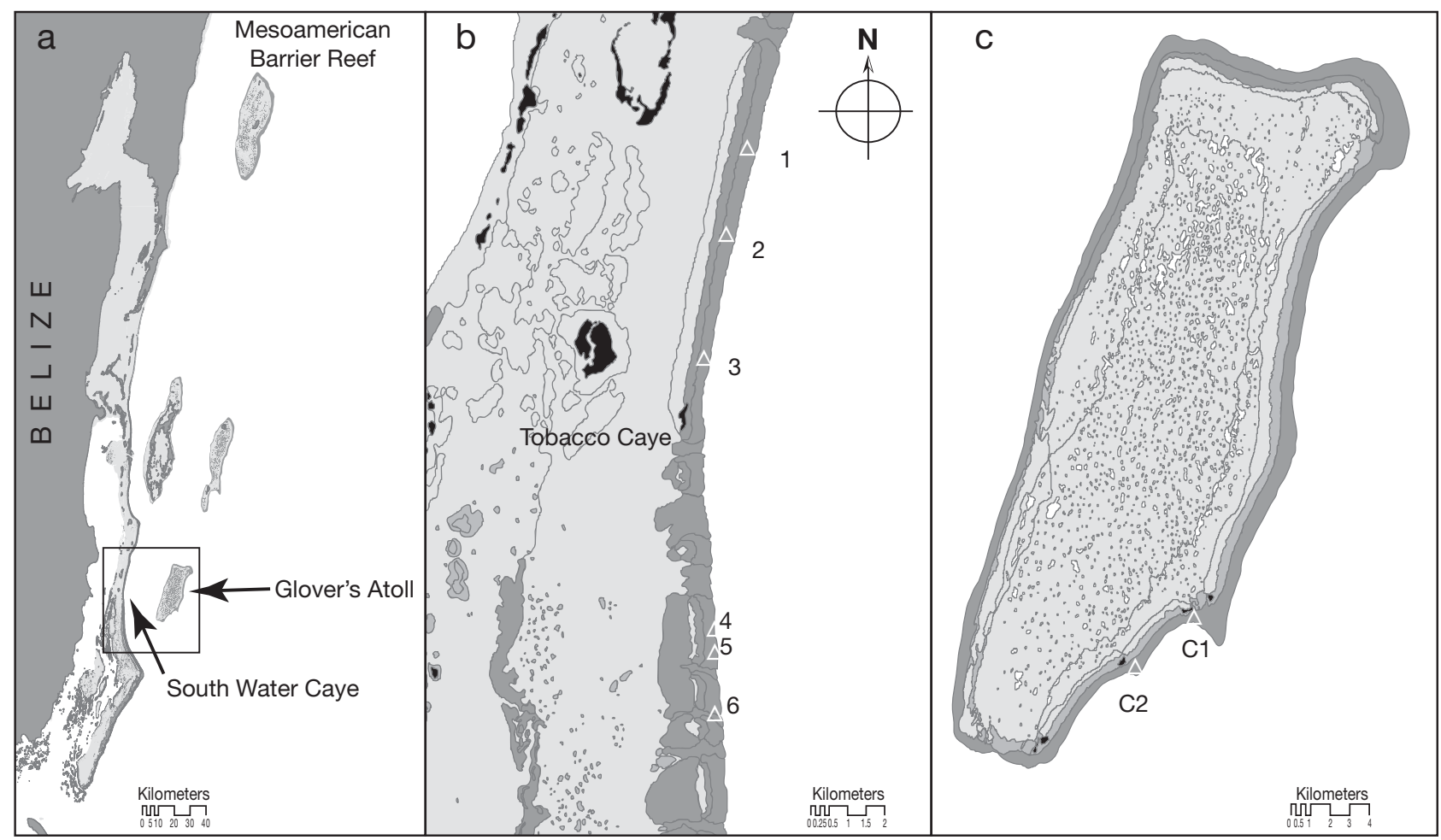

Fig. 1. (a) Belize Barrier Reef. (b) Study sites (1-6) in the South Water Caye area, and (c) control sites (C1, C2) at Glover's Reef

Table 1. Sampling details for the start and end of the study

\begin{tabular}{|c|c|c|c|c|}
\hline \multirow[t]{2}{*}{ Fish group } & \multicolumn{2}{|r|}{ - Start } & & \multirow[b]{2}{*}{ Method } \\
\hline & Year & Method & Year & \\
\hline Large grouper, snappers & 2002 & Transects $(50 \times 4 \mathrm{~m})$ & $\begin{array}{l}2008 \text { (Sites 4-6), } \\
2009 \text { (Sites 1-3) }\end{array}$ & Transects $(50 \times 4 \mathrm{~m})$ \\
\hline Parrotfish & 2002 & Transects $(30 \times 4 \mathrm{~m})$ & 2009 & Transects $(30 \times 4 \mathrm{~m})$ \\
\hline $\begin{array}{l}\text { Mesopredators } \\
\text { (coney, graysby, red hind) }\end{array}$ & 2002 & Transects $(50 \times 4 \mathrm{~m})$ & 2009 & $\begin{array}{l}\text { Transects }(50 \times 4 \mathrm{~m})(\text { Sites } 1-3) \text {, } \\
25 \mathrm{~m}^{2} \text { plots }(\text { Site } 4)\end{array}$ \\
\hline Damselfish & 2002 & Transects $(30 \times 2 \mathrm{~m})$ & 2009 & $\begin{array}{l}\left.25 \mathrm{~m}^{2} \text { plots (Sites } 4-6\right) \\
160 \mathrm{~m}^{2} \text { plots at Glover's Reef }\end{array}$ \\
\hline
\end{tabular}




\section{Fisheries data}

Fisheries catch data were compiled from a fisherydependent monitoring program designed to determine trends in landings and fishing pressure at the Glover's Reef Marine Reserve. The sampling program began in 2004 and collected data at sea from fishers who operated sailboats and originated primarily from Sarteneja Village. Sampling was done on 3 consecutive days per month. On each sampling trip, approximately 3 sailboats were sampled with each sailboat having $\sim 5$ to 8 fishers who used individual 'dories' to fish. For each fisher's catch, the name of the fisher, species caught, fishing gear and total fishing effort (hours fished) were recorded. The fork length size $(\mathrm{cm})$ and weight $(\mathrm{g})$ were also recorded for finfish. Fisher behaviour at Glover's Reef is similar to that on the barrier reef (D. Wesby, pers. comm.).

\section{Fish census}

Sample units were scaled to the density and habitat of fish groups so that less common, wider-ranging fishes were sampled using larger units. Data for 4 major fish groups are presented here: (1) Large serranids (mean adult total length [TL]: 40 to $65 \mathrm{~cm}$ species $^{-1}$ ) and lutjanids were sampled using 6 to 12 transects, each measuring $50 \times 4 \mathrm{~m}$ (Table 1). (2) Scarids were surveyed using 10 transects of $30 \times 4 \mathrm{~m}$. (3) Pomacentrids were sampled using 6 transects of $30 \times$ $2 \mathrm{~m}$ in 2002. However, the follow-up pomacentrid surveys in 2009 were carried out using replicate $5 \times 5 \mathrm{~m}$ plots at Sites $4-6(\mathrm{n}=30$ for Site $4, \mathrm{n}=5$ for Site $5, \mathrm{n}=$ 6 for Site 6) and 3 large $160 \mathrm{~m}^{2}$ plots at each of 2 control sites in the reserve at Glover's Reef. Although data were collected for both adult and juvenile damselfish, only the adult data are reported here be- cause juvenile density was expected to vary greatly without necessarily influencing long-term demographic trends of the population. Juveniles were discriminated on the basis of colouration (Stegastes planifrons) and size (S. bicolor, $<3 \mathrm{~cm}$ ). (4) Smaller serranids, whose mean TL ranges from 14 to $24 \mathrm{~cm}$ and comprises the mesopredators Cephalopholis fulvus, C. cruentatus, and Epinephelus guttatus, were sampled using six $50 \times 4 \mathrm{~m}$ transects in 2002. Transects were repeated in 2009 at Sites 1-3 and plots were used at Site 4 (Table 1), but no data were available from Glover's Reef. Fish were identified to species and their TL estimated to the nearest $\mathrm{cm}$. Body sizes were converted to biomass using published allometric relationships (Bohnsack \& Harper 1988).

A Caribbean regional mean biomass for large-bodied grouper was obtained from the 444 forereef sites in the Atlantic Gulf Rapid Reef Assessment (AGRRA) database (Kramer 2003).

\section{Analyses}

Univariate analyses of fish biomass or density over time were carried out using generalised linear mixed effects models (Pinheiro \& Bates 2000), with time as a fixed effect. We were not interested in site-level variability and therefore entered sites as a random effect into the main statistical models reported. However, given that some results are plotted for individual sites, we ran additional analyses with sites as a fixed effect so that significant differences could be labelled. Models used the appropriate error family, including quasi-Poisson where data were overdispersed (Table 2). Changes in parrotfish community structure were examined using multivariate methods, including analysis of similarities (ANOSIM) and similarity pecentage analysis (SIMPER) (Clarke 1993).

Table 2. Summary of non-linear mixed effects models for South Water Caye, Belize with site as a random effect and time as the main effect. First sampling interval, 2002, was the reference level

\begin{tabular}{|llccc|}
\hline Analysis & Errors & \multicolumn{3}{c|}{ Coefficients (SE) } \\
\cline { 3 - 4 } & & Intercept & Time $(2008 / 09)$ \\
\hline Sighting presence of large grouper per transect & Binomial & $-1.58(0.47)$ & $-2.66(1.1)$ & $<0.01$ \\
Snapper biomass & Identity & $1678(511)$ & $2274(773)$ & $<0.001$ \\
Parrotfish biomass & Identity & $1357(74)$ & $-607(100)$ & $<0.001$ \\
Parrotfish biomass (control sites) & Identity & $1806(287)$ & $309(245)$ & 0.21 \\
Mesopredator biomass & Identity & $89.4(98.7)$ & $422(102)$ & $<0.0001$ \\
Density of coney Cephalopholis fulvus & Poisson & $-1.51(0.35)$ & $0.87(0.43)$ & $<0.05$ \\
Density of graysby C. cruentatus & Poisson & $-1.50(0.35)$ & $1.39(0.40)$ & $<0.0001$ \\
Density of red hind Epinephelus guttatus & Poisson & $-2.90(0.71)$ & $2.44(0.74)$ & $<0.01$ \\
Density of bicolor damselfish Stegastes partitus & Quasipoisson & $2.83(0.14)$ & $-0.69(0.19)$ & $<0.001$ \\
Density of threespot damselfish S. planifrons & Quasipoisson & $2.64(0.36)$ & $-0.82(0.21)$ & $<0.001$ \\
\hline
\end{tabular}




\section{RESULTS}

\section{Direct temporal effects of fishing}

Loss of large groupers (top predators)

Large groupers were defined as those serranid species reaching a large adult size $(40-65 \mathrm{~cm}$ TL) and included Epinephelus striatus, Mycteroperca bonaci, and $M$. tigris. No individuals of body size $<40 \mathrm{~cm}$ were observed in the outer reef habitat. In 2002, observations of large-bodied grouper were reasonably frequent in the South Water Caye area and the probability of sightings on a transect was $21 \%$ (Table 3). The mean biomass of grouper averaged $36 \mathrm{~kg} \mathrm{ha}^{-1}$, which was greater than the Caribbean average of $26 \mathrm{~kg} \mathrm{ha}^{-1}$. By 2008/09, large-grouper densities had fallen so far that it became difficult to estimate the biomass of their populations meaningfully. The probability of sighting at least one grouper per transect at a site had fallen from $21 \%$ in 2002 to only $2 \%$ (Table 3 ). This decline in density was highly significant (Table 2).

Loss of snappers (commercially important predators)

Snappers (Lutjanidae) were found at all 6 sites in 2002 but exhibited a 7 -fold and significant decline in biomass by 2008/09 (Fig. 2, Table 2). In 2002, >90\% of the total snapper biomass comprised the yellowtail snapper Ocyurus chrysurus. This species experienced an 8 -fold decline by 2008/09 and its dominance fell to $79 \%$ of the snapper community (by biomass). The mean size of yellowtail snapper did not change between census dates (non significant $t$-test), implying that the major changes in biomass were driven mostly by reduced density of individuals.

\section{Delayed loss of herbivores (key herbivore)}

In the 1990s parrotfish were held in low esteem and were barely harvested (Koslow et al. 1994). By 2004,

Table 3. Decline in large-bodied grouper observation (large serranid observation per $200 \mathrm{~m}^{2}$ ) over time. CI: confidence intervals

\begin{tabular}{|lcc|}
\hline Year & $\mathrm{p}$ & $95 \% \mathrm{CI}$ \\
\hline 2002 & 0.21 & $0.12-0.32$ \\
$2008 / 2009$ & 0.02 & $0.0005-0.11$ \\
\hline
\end{tabular}

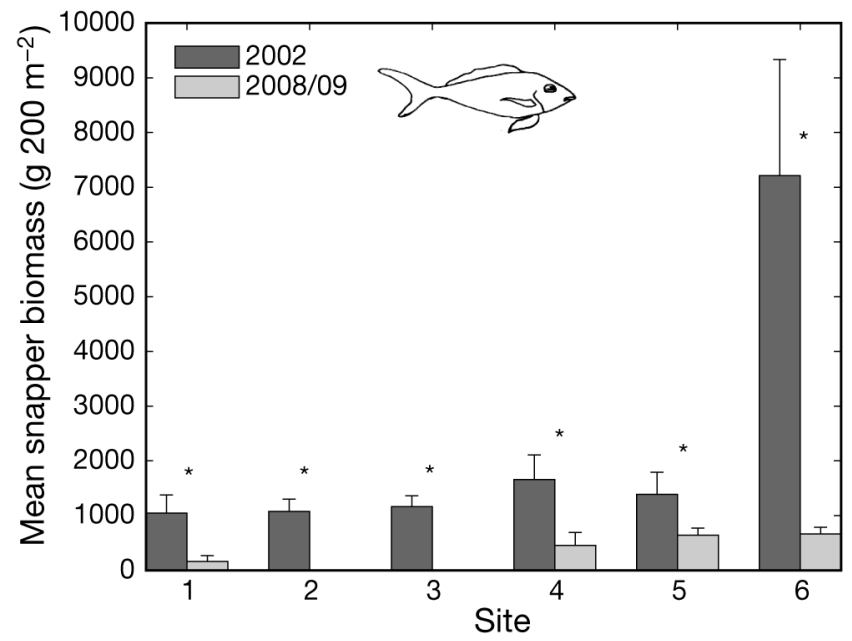

Fig. 2. Decline (+SEM) in snapper (Lutjanidae) in the South Water Caye region. * Significant differences

when catch records began in fished areas of Glover's Reef, parrotfish comprised 6\% (by frequency) of the fishes caught using spear. This proportion rose to $51 \%$ in 2005 and then settled between $13 \%$ (2007), $17 \%(2006)$ and $21 \%$ (2008). The mean TL of harvested parrotfishes between 2004 and 2008 was $39 \pm$ $3.4 \mathrm{~cm}( \pm \mathrm{SD})$. The main fishing method is spear.

Parrotfish biomass in the South Water Caye area declined strikingly over the 7 to 8 yr period between censuses (Fig. 3, Table 2). Overall, parrotfish biomass declined by $41 \%$ but the pattern varied among sites, being most severe at the northern sites near the islands of Tobacco Cay and South Water Caye (Fig. 3; decline at Sites 1-3 were 85, 74, and $43 \%$, respectively). Changes in biomass were largely a result of changes in fish density because the mean size of terminal phase (TP) and intermediate phase (IP)

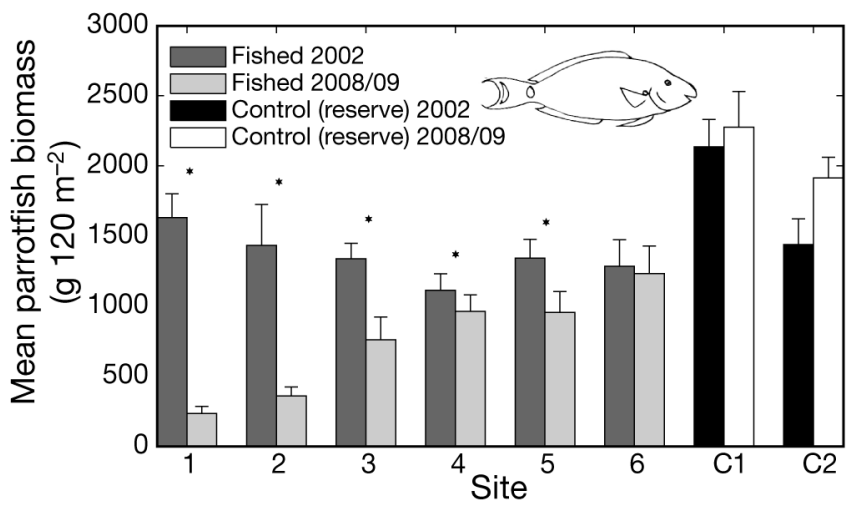

Fig. 3. Reduction (+SEM) in parrotfish biomass at reserve sites and control sites (C1 and C2) at Glover's Reef Marine Reserve where no fishing takes place. * Significant differences 
stoplight parrotfish Sparisoma viride, the most sought-after parrotfish species, did not differ over time (non-significant $t$-tests). No decline in biomass was observed at the southern-most site at South Water Caye or in the 'control' unfished marine reserve at Glover's Reef (Fig. 3). Note that the southern-most sites at South Water Caye were furthest from island settlements and likely experienced considerably less fishing than those sites further north (Mumby et al. 2004).

The structure of the parrotfish community exhibited modest but highly significant changes between census dates (Fig. 4), with an ANOSIM rho of $0.32(\mathrm{p}=0.002)$. Averaging across sites, SIMPER analysis revealed that the 3 most important differences were found in the biomasses of stoplight IP (18\% of mean dissimilarity over time), stoplight TP (17\% of dissimilarity), and striped (Scarus iserti) TP (11\% dissimilarity).

\section{Indirect temporal effects of fishing \\ Positive response of mesopredators}

Small-bodied serranids responded positively with a highly significant increase in mean biomass equivalent to $880 \%$ of the 2002 level (Fig. 5, Table 2). All 3 mesopredators increased in their density (Fig. 6, Table 2), but only the Cephalopholis species (e.g. coney and graysby) exhibited an increase in body size (Fig. 6). Of these, the coney C. fulvus increased in mean TL fairly dramatically from 16.5 to $27.35 \mathrm{~cm}$ ( $t$-test, $\mathrm{p}<0.001)$, whereas the graysby $C$. cruentatus exhibited a significant but only modest increase from 15.5 to $18.2 \mathrm{~cm}(\mathrm{p}=0.002)$.

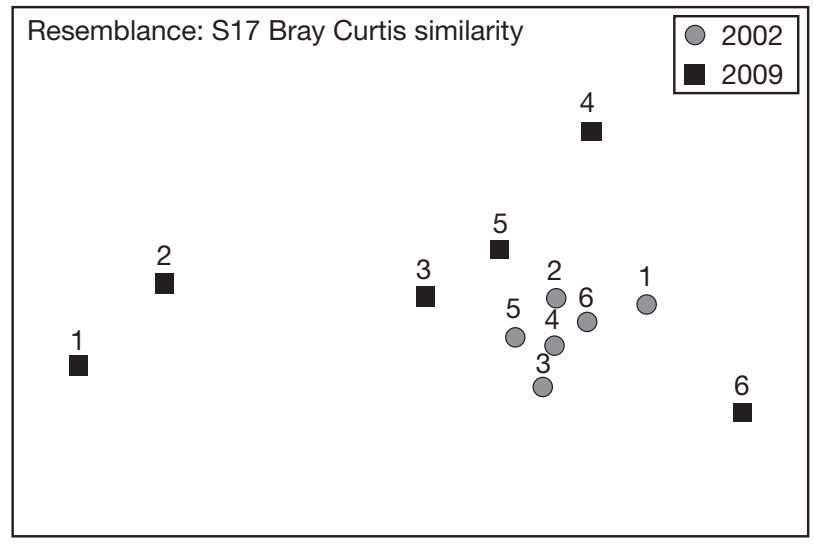

Fig. 4. Community structure of parrotfish over time at 6 sites of the South Water Caye area for $2002(\bigcirc)$ and 2009 (

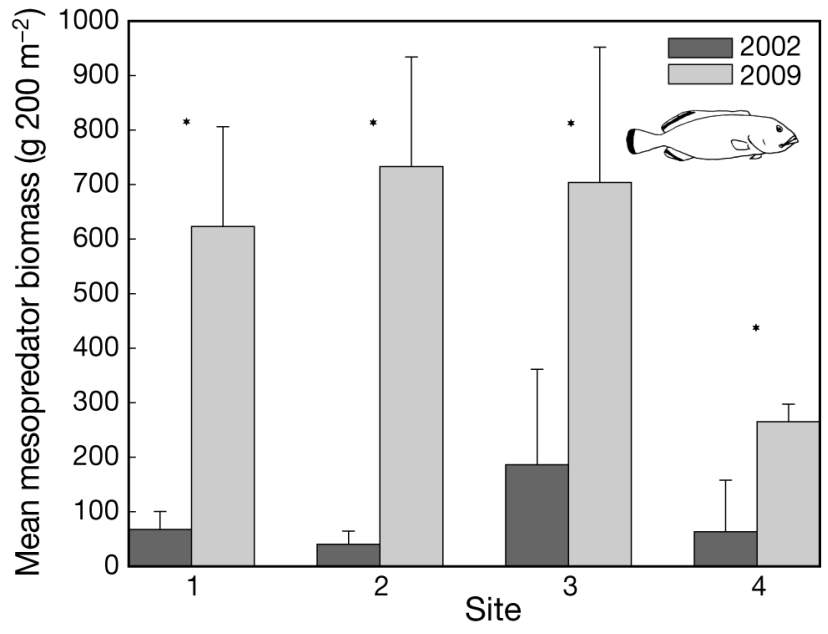

Fig. 5. Cephalopholis fulvus, C. cruentatus, and Epinephelus guttatus. Positive response (increase in biomass + SEM) of mesopredators to fishing at sites in the South Water Caye area. ${ }^{*}$ Significant differences

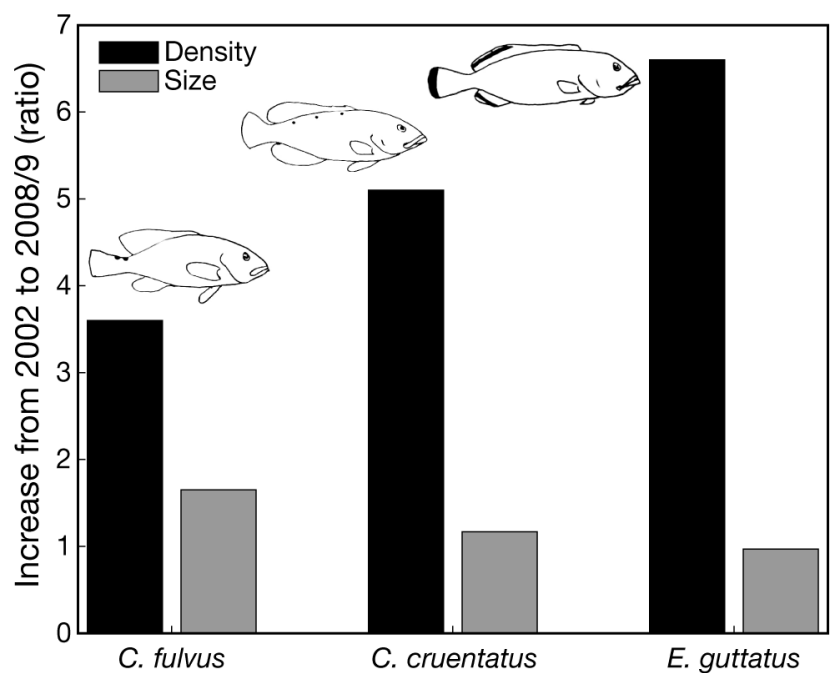

Fig. 6. Cephalopholis fulvus, C. cruentatus, and Epinephelus guttatus. Relative changes in mesopredator density and body size between 2002 and 2009 in the South Water Caye area

Negative response of damselfishes

The 2 most abundant damselfishes in the habitat, the bicolor Stegastes partitus and threespot S. planifrons, exhibited a marked decline in adult abundance over time (Fig. 7, Table 2). Across the 3 sites for which data were available, the decline in abundance of bicolor damselfish averaged $45 \%$ of 2002 levels, and a similar decline of $43 \%$ was found for threespot damselfish. However, no significant decline occurred in either species at the 2 control sites in the Glover's Reef marine reserve. The mean density of adult bicolor damselfish in 2002 was 40.8 

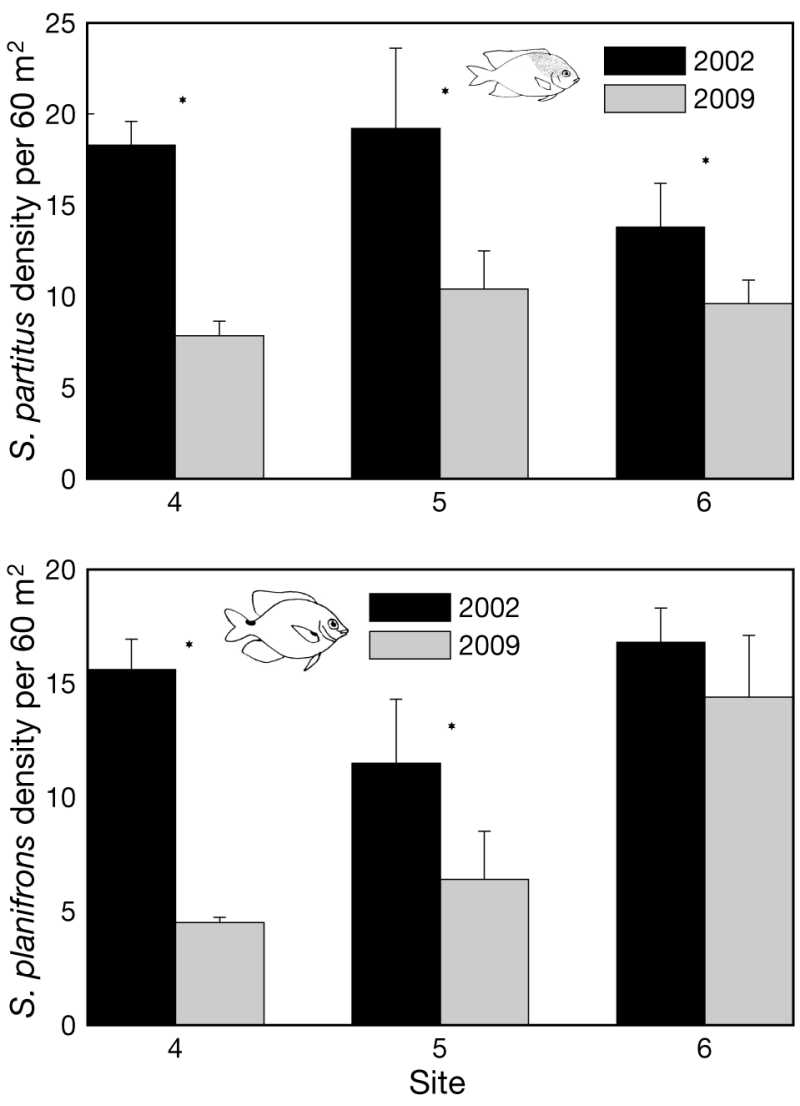

Fig. 7. Stegastes partitus and S. planifrons. Decline (+SEM) in damselfish density at 3 sites of the South Water Caye area. ${ }^{*}$ Significant differences

$( \pm 2.495 \% \mathrm{CI})$ at Long Caye and $30.1( \pm 5.9)$ at Middle Caye. Densities at these sites in 2009 were well within the 2002 confidence interval, at 39.6 and 27.5, respectively. Similarly, the mean adult density of threespot damselfish in 2002 was $14.0( \pm 4.8)$ at Long Cay and $4.3( \pm 3.2)$ at Middle Cay, and 2009 densities were almost identical to 2002 values at 14.3 and 4.0, respectively.

\section{Response of reef macroalgae}

A quantitative assessment of change in benthic cover was not attempted mostly because it would not have been possible to attribute causality to any change in the fish community. However, an anecdotal observation is included because it implies that the ecosystem is heavily undergrazed (i.e. rates of net primary productivity exceed the rates of consumption by herbivores). The calcified macroalga Halimeda tuna was frequently observed growing on the tops of dead Montastraea annularis colonies (Fig. 8). The tops of these corals are the most intensively grazed microhabitat by parrotfishes and are usually maintained as short turfs by grazers (P. J. Mumby unpubl. data). Over the study period we observed the expansion of $H$. tuna from crevices to the apex of dead coral colonies; this strongly implies that grazing levels have declined considerably because this alga had not been observed in this microhabitat in 2002 or at control sites at Glover's Reef.

\section{DISCUSSION}

Parrotfishes were barely exploited in 2002, but records of fishing activities from nearby Glover's Reef suggest that the proportion of parrotfishes in the catch at least doubled between 2004 and 2008. Informal discussions with fishers throughout Belize implied that the rise in parrotfish fishing reflected difficulties in catching preferred groupers and snappers (P. J. Mumby pers. obs.). Our data from South Water Caye clearly provide quantitative support for this view because the biomass and abundance of these groups has declined dramatically since 2002. Largegrouper abundance was already low in 2002, largely because of an extensive history of exploitation (Sala et al. 2001), but by 2009 it had dropped to a level that was barely measurable using 1200 to $2400 \mathrm{~m}^{2}$ of transects. Similarly, snapper biomass dropped 7 -fold. Our results are therefore consistent with 'fishing down of the food web' (Pauly et al. 1998) rather than 'fishing through the food web' (Essington et al. 2006), in that fishers moved to exploit less desirable species, of a lower trophic level, as it became increasingly difficult to harvest species of higher trophic levels (Fig. 9).

Despite assertions that recent declines in herbivore biomass result from habitat degradation (Paddack et al. 2009), our results suggest that fishing is a more parsimonious explanation for the major decline in scarid biomass in Belize. There are 2 lines of evidence to support this statement. First, there has been no notable change in habitat structure during the sampling interval of this study. In principle, habitat could have been lost by hurricane damage or mortality of the structurally complex coral genus Acropora as shown by Jones et al. (2004). However, hurricanes have not impacted these reefs significantly between 2002-2008/09, and Acropora was already scarce (cover <1\%) in the study area by 2002 and has remained so. Second, parrotfish declines were confined to fished sites and biomass exhibited no change at our no-take control sites at Glover's Reef, which were sampled concurrently but lacked fishing effects. 

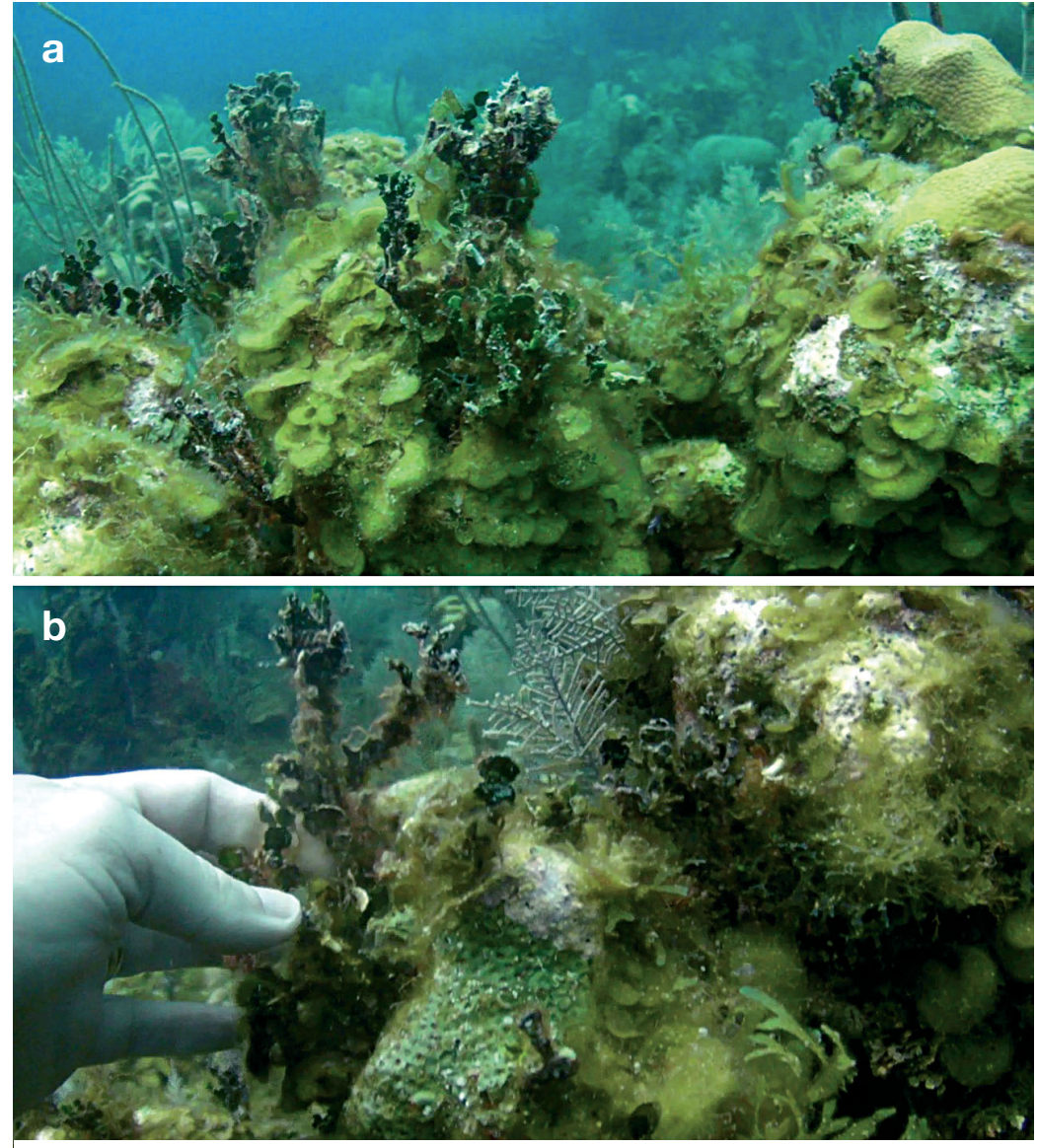

Fig. 8. Growth of (a) Lobophora variegata (dominating coral) and (b) Halimeda tuna (held in hand) on the tops of dead Montastraea colonies in the South Water Caye area in 2009

While fishing has directly reduced the biomasses of large grouper, snapper and parrotfish, our results also provide insights into the indirect effects of fishing. The first insight highlights the time scale needed for prey release from predators. Here, we found that the decline in large-bodied grouper was accompanied by at least an 8 -fold increase in mesopredators over a 6 to $7 \mathrm{yr}$ period. While such inverse correlations have been reported among sites in Florida and the Bahamas (Chiappone et al. 2000), they have not been reported over time. Our results suggest that a numeric response of mesopredators can be rapid, requiring only a few years, and is consistent with mesopredator releases following removal of apex predators in a range of ecosystems (Ritchie \& Johnson 2009). The mechanisms behind such shifts in mesopredators might be complex. Direct predation on small serranids by large grouper has been observed (Stallings 2008) and inferred from inventories of stomach contents (Randall 1967). Reduced predation pressure, following fishing of large grouper, may have led to the observed increases in small serranids, possibly exacerbated by a redistribution from shallower water onto deeper reefs, as witnessed in Curaçao (Nagelkerken et al. 2005). Furthermore, Stallings (2008) demonstrated risk-averse foraging by small serranids in the presence of larger grouper. Experimentally manipulated densities of Nassau grouper Epinephelus striatus influenced the behaviour and growth rate of the mesopredator Cephalopholis spp.: under higher risk of predation, Cephalopholis spent less time foraging and exhibited reduced growth rates, and the abundance of juvenile prey fishes increased (Stallings 2008). The less cryptic behaviour of small serranids might have increased observation rates on transects in 2009, but the dramatic increases in density and body size of some species are extremely unlikely to have been a surveying artefact associated with a change in fish behaviour. More importantly, the removal of large grouper has likely increased both the abundance of mesopredators and increased the time they spend foraging, thereby causing a marked increase in predation pressure.

While we cannot discount an effect of reef sharks, such as Carcharhinus perezi, on the predation of mesopredators, available evidence from the region (Glover's Atoll) has found no change in shark abundance between 2001 and 2004 (Pikitch et al. 2005), which implies that a mesopredator release is unlikely to be attributable to declines in the abundance of sharks. Other possible predators of mesopredators, such as barracuda Sphyraena barracuda, were rarely observed throughout the study period and have been fished intensively for many years in Belize.

With little obvious change in habitat availability, the anticipated rise of predation pressure by mesopredators is likely to be responsible for the decline in density of adult damselfish (Fig. 9). Several studies document an inverse relationship between damselfish and predator abundance (Hixon \& Beets 1993, Graham et al. 2003, Holbrook \& Schmitt 2003, Belmaker et al. 2009). Further support for this from a recent empirical study of mesopredator predation (Cephalopholis) found reductions in the recruitment 

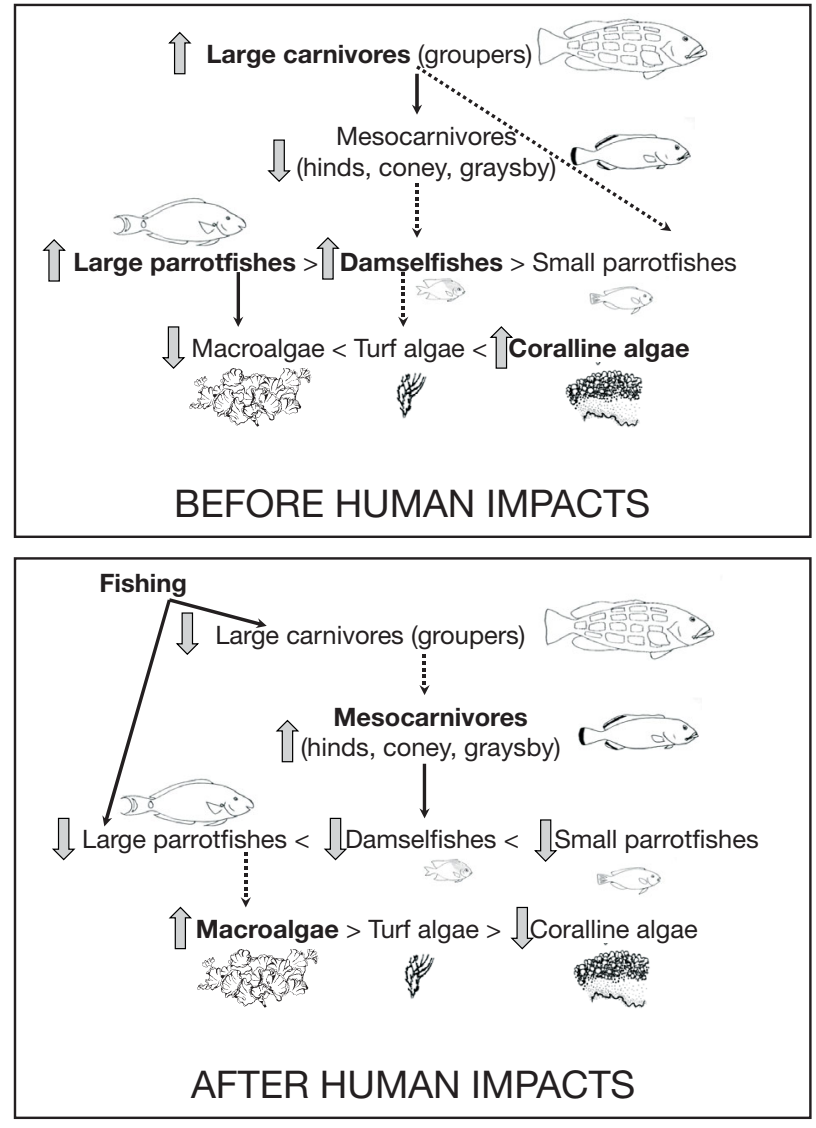

Fig. 9. Synthesis of fishing impacts on reef foodweb structure and function. Boldface: species dominating foodweb structure. Gray arrows: abundance trends. Black arrows: strong ecological interactors. Dotted arrows: weak or nonexistent ecological interactors. Within a trophic level competitive interactions can function like a 'module' (sensu Paine 1980). Modules usually have a competitive hierarchy illustrated with 'dominant species' > 'subordinate species'

of several Caribbean fishes including the damselfish Stegastes leucostictus and striped parrotfish Scarus iserti (Stallings 2009). No effect was found on bicolor damselfish in the Stallings (2009) study, but this may be partly explained by its relative low recruitment rate at the study site. However, other studies have specifically reported a significant negative relationship between predation and bicolor damselfish (Almany 2004, Figueira et al. 2008). It is unclear whether mesopredators are preying upon adult damselfishes, but groupers of $\sim 20 \mathrm{~cm}$ certainly take prey up to $50 \mathrm{~mm}$ (Kingsford 1992).

An alternative explanation for the observed decline in damselfish density would be a sustained decline in larval supply prior to our surveys in 2009. However, several lines of evidence and the principle of parsimony suggest that is unlikely. First, the absence of any decline in damselfish density at our control sites, lacking fishing, provides indirect evidence to support trophic mechanisms. Secondly, for low larval supply to be a plausible mechanism we would have to accept that (1) supply declined only on the Barrier Reef but not at nearby Glover's Reef, (2) that both damselfish species were effected simultaneously, (3) that populations of both damselfishes are strongly recruitment limited such that a short-term reduction in larval supply constrains adult abundance, and (4) that the decline was sufficiently persistent to limit adult populations. Given that available data do not support the view that Caribbean damselfish (specifically, Stegastes partitus) are strongly recruitment limited (Robertson 1996, Paris \& Cowen 2004), it seems unlikely that a reduction in larval supply-even if it occurred-would have resulted in such a severe deleterious impact on adults.

Most studies of the processes influencing damselfish abundance on Caribbean reefs have focused on habitat choice, recruitment and competition (Itzkowitz 1977, Williams 1978, Robertson 1984, Sponaugle \& Cowen 1996, Gutiérrez 1998). The role of predation in determining damselfish abundance has received relatively little attention until recently. Manipulations of predator access to damselfish in Jamaica (Williams 1981) found no impact on density, although the study area was likely to contain relatively few predators because of the long history of fishing in Jamaica. A recent study regressed piscivore abundance on the density of threespot damselfish across 3 countries, and included 2 sites from our study area that were sampled in 2001 (Precht et al. 2010). The study found no significant relationship between piscivore and prey abundance and concluded that coral density and rugosity were the most strongly correlated variables to damselfish density. This is undoubtedly correct in a spatial analysis but, as discussed above, may not apply to temporal studies in which habitat architecture did not change. In other words, there is little doubt that habitat availability plays an important role in driving the distribution of many damselfish species, and threespots in particular (Robertson 1996). However, the real challenge for analyses of spatial pattern, like Precht et al. (2010), is to distinguish an effect of predation over and above that of habitat complexity. This requires a dataset which is large enough that multiple estimates of predator abundance occur for at least several levels of habitat complexity. Although Precht et al. (2010) increase their statistical power by pooling data collected at multiple scales, their sample size of 12 observations may have limited their ability to resolve 
the effects of 2 independent drivers, particularly when one (rugosity) is so strong.

An alternative, albeit less parsimonius, explanation of the disparity between our study and that of Precht et al. (2010) is that observable predator-prey relationships are only transient. The 6 to $7 \mathrm{yr}$ period of our study witnessed a large 8-fold change in mesopredator biomass which appears likely to have negatively impacted the density of resident damselfish. In principle, the population explosion of mesopredators, if trophically limited, could have been facilitated by the high densities of their prey (damselfish) in 2002. However, once prey densities decline, as has happened here (e.g. Fig. 9), mesopredator densities fall, generating predator-prey oscillations or new equilibrial densities that are closer to the original densities and therefore more difficult to detect. If this were the case, then surveys of locations where mesopredators and prey are at equilibrium (i.e. where they have not recently been perturbed by say a collapse in numbers of larger predators) might struggle to detect a significant difference in prey density among sites. Since the Precht et al. (2010) study surveyed South Water Caye prior to the rapid rise of mesopredators we describe, it is possible that many of their sites were at equilibrium and that damselfish densities exhibit weak long-term responses to altered predator density. Continued monitoring of our sites in Belize may resolve the temporal dynamics of these predator-prey relationships.

We note that the continued paucity of strongly branched Acropora coral on many Caribbean reefs, which is a favoured habitat of threespot damselfish (but not bicolors, which prefer rubble), may have increased the vulnerability of damselfish populations to changes in predator abundance. Thus, our inference of some predator limitation on damselfish remains consistent with early studies that could not detect predation impacts on damselfish within thickets of Acropora (Williams 1981). In fact, there is fossil evidence from Pleistocene coral reefs in Jamaica of predator-damselfish coexistence in acroporid thickets (Kaufman 1981). However, a geologically unprecedented change in Caribbean coral reef habitat architecture resulted from the acroporid mass mortality during the 1980s (Pandolfi \& Jackson 2006), and this may have ushered in a new predator-prey dynamic for territorial damselfishes.

The mean harvested size of parrotfishes at Glover's Reef was $39 \mathrm{~cm}$ (SD $3.4 \mathrm{~cm})$, which strongly implies that only adults of large-bodied species are being harvested. Therefore, direct effects of fishing are the most obvious explanation for declines in the large- bodied (predator resistant) stoplight parrotfish at South Water Caye. However, fishing is unlikely to explain the decline in abundance of the smaller (predator susceptible) striped parrotfish that has rarely exceeded a length of $25 \mathrm{~cm}$ in Belize (P. J. Mumby unpubl. data from 1998 onwards). Stallings (2009) found that mesopredators in the genus Cephalopholis had a significant deleterious impact on recruitment of striped parrotfish, and therefore trophic cascades might explain some of the decline in this species, and potentially in larger-bodied parrotfishes as well.

The decline in parrotfish biomass, particularly in large-bodied species that often undertake disproportionately high grazing (Mumby et al. 2006, Arnold et al. 2010), is a matter of concern. Indeed, a major decline in grazing is consistent with our anecdotal observation of large, erect macrophytes colonising previously unexploited microhabitats that are usually heavily grazed (although a decline in water quality might also have contributed to this, see Koltes \& Opishinski 2009). Studies elsewhere in the Caribbean have shown that low levels of grazing can lead to reduced coral recruitment and hinder recovery (Mumby \& Harborne 2010), and reefs in the South Water Caye area appear to be highly susceptible to grazer-driven phase shifts (R. S. Steneck et al. unpubl.). The combined evidence implies that the resilience of coral reefs in this part of Belize might be significantly impaired (Fig. 9).

While reefs in central Belize have exhibited a number of troubling trends, there are 3 grounds for optimism. The first is a speculative hypothesis. In a recent study, Arnold et al. (2010) demonstrated that coral recruitment declined dramatically inside territorial damselfish territories, largely in response to the inhibitory effects of thick algal turfs on water flow. Thus, if the observed depletion of damselfish density persists, this may alleviate some of the pressure upon coral recruitment imposed by a decline in grazers they create (though high levels of macroalgae resulting from declines in macroherbivores remain a serious concern). Second, Belize is moving ahead with legislation to enforce no-fishing sanctuaries within the reef system, as evidenced by the relatively recent implementation of protection within parts of South Water Caye. The third cause for optimism is that the Government of Belize recently passed a law (Montero 2009) to ban the harvesting of major grazers (parrotfishes and surgeonfishes), protect spawning aggregations of Nassau grouper Epinephelus striatus, and set an intermediate-size slot for Nassau grouper fisheries (see Steneck et al. 2009). Moreover, the law requires Nassau grouper to be landed whole and 
other landed fish to possess a patch of skin $(5 \times$ $2.5 \mathrm{~cm})$ to ensure verification of identification and therefore facilitate enforcement. If enforced, these regulations will constitute the state-of-the-art in taking a proactive approach towards managing ecosystem process and populations of vulnerable species.

Acknowledgements. This study was funded by NERC, the National Geographic Society, EU Force, and ARC grants to P.J.M., a joint NFWF grant to R.S.S. and P.J.M., and a NERC fellowship to A.R.H. We thank the Belize Department of Fisheries for granting us permission to undertake this work.

\section{LITERATURE CITED}

Almany GR (2004) Does increased habitat complexity reduce predation and competition in coral reef fish assemblages? Oikos 106:275-284

> Arnold SN, Steneck RS, Mumby PJ (2010) Running the gauntlet: inhibitory effects of algal turfs on the process of coral recruitment. Mar Ecol Prog Ser 414:91-105

Ault JS, Bohnsack JA, Meester GA (1998) A retrospective (1979-1996) multispecies assessment of coral reef fish stocks in the Florida Keys. Fish Bull 96:395-414

> Belmaker J, Ziv Y, Shashar N (2009) Habitat patchiness and predation modify the distribution of a coral-dwelling damselfish. Mar Biol 156:447-454

Bohnsack JA, Harper DE (1988) Length-weight relationships of selected marine reef fishes from the southeastern United States and the Caribbean. NOAA Tech Memo NMFS-SEFC-215

> Cheung WWL, Watson R, Morato T, Pitcher TJ, Pauly D (2007) Intrinsic vulnerability in the global fish catch. Mar Ecol Prog Ser 333:1-12

Chiappone M, Sluka R, Sullivan Sealey KM (2000) Groupers (Pisces: Serranidae) in fished and protected areas of the Florida Keys, Bahamas and northern Caribbean. Mar Ecol Prog Ser 198:261-272

Clarke KR (1993) Non-parametric multivariate analyses of changes in community structure. Aust J Ecol 18:117-143

Coleman FC, Koenig CC, Huntsman GR, Musik JA and others (2000) Long-lived reef fishes: the groupersnapper complex. Fisheries (Bethesda) 25:14-28

Essington TE, Beaudreau AH, Wiedenmann J (2006) Fishing through marine food webs. Proc Natl Acad Sci USA 103: 3171-3175

Estes JA, Terborgh J, Brashares JS, Power ME and others (2011) Trophic downgrading of planet Earth. Science 333:301-306

Figueira WF, Booth DJ, Gregson MA (2008) Selective mortality of a coral reef damselfish: role of predator-competitor synergisms. Oecologia 156:215-226

Friedlander A, Beets J (2008) Temporal trends in reef fish assemblages inside Virgin Islands National Park and around St. John, US Virgin Islands, 1988-2006. NOAA Tech Memo NOS NCCOS 70, Silver Spring, MD

> Friedlander AM, DeMartini EE (2002) Contrasts in density, size, and biomass of reef fishes between the northwestern and the main Hawaiian islands: the effects of fishing down apex predators. Mar Ecol Prog Ser 230:253-264

Graham NAJ, Evans RD, Russ GR (2003) The effects of marine reserve protection on the trophic relationships of reef fishes on the Great Barrier Reef. Environ Conserv 30: 200-208

Gutiérrez L (1998) Habitat selection by recruits establishes local patterns of adult distribution in two species of damselfishes: Stegastes dorsopunicans and S. planifrons. Oecologia 115:268-277

> Harborne AR, Mumby PJ, Kappel CV, Dahlgren CP and others (2008) Reserve effects and natural variation in coral reef communities. J Appl Ecol 45:1010-1018

$>$ Hay ME (1984) Patterns of fish and urchin grazing on Caribbean coral reefs: Are previous results typical? Ecology 65:446-454

- Hixon MA, Beets JP (1993) Predation, prey refuges, and the structure of coral-reef fish assemblages. Ecol Monogr 63: 77-101

> Holbrook SJ, Schmitt RJ (2003) Spatial and temporal variation in mortality of newly settled damselfish: patterns, causes and co-variation with settlement. Oecologia 135: 532-541

> Itzkowitz M (1977) Spatial organization of the Jamaican damselfish community. J Exp Mar Biol Ecol 28:217-241

> Jackson JBC, Kirby MX, Berger WH, Bjorndal KA and others (2001) Historical overfishing and the recent collapse of coastal ecosystems. Science 293:629-637

Jennings S, Kaiser MJ (1998) The effects of fishing on marine ecosystems. Adv Mar Biol 34:201-352

> Jennings S, Polunin NVC (1995) Comparative size and composition of yield of six Fijian reef fisheries. J Fish Biol 46: 28-46

> Jennings S, Polunin NVC (1997) Impacts of predator depletion by fishing on the biomass and diversity of non-target reef fish communities. Coral Reefs 16:71-82

Jennings S, Grandcourt EM, Polunin NVC (1995) The effects of fishing on the diversity, biomass and trophic structure of Seychelles' reef fish communities. Coral Reefs 14:225-235

> Jones GP, McCormick MI, Srinivasan M, Eagle JV (2004) Coral decline threatens fish biodiversity in marine reserves. Proc Natl Acad Sci USA 101:8251-8253

Kaufman L (1981) There was biological disturbance on Pleistocene coral reefs. Paleobiology 7:527-532

Kingsford MJ (1992) Spatial and temporal variation in predation on reef fishes by coral trout (Plectropomus leopardus, Serranidae). Coral Reefs 11:193-198

Koltes KH, Opishinski TB (2009) Patterns of water quality and movement in the vicinity of Carrie Bow Cay, Belize. Smithson Contrib Mar Sci 38:380-390

- Koslow JA, Hanley F, Wicklund R (1988) Effects of fishing on reef fish communities at Pedro Bank and Port Royal Cays, Jamaica. Mar Ecol Prog Ser 43:201-202

Koslow JA, Aiken K, Auil S, Clemetson A (1994) Catch and effort analysis of Jamaica and Belize. Fish Bull 92: 737-747

Kramer PA (2003) Synthesis of coral reef health indicators for the Western Atlantic: results of the AGRRA program (1997-2000). Atoll Res Bull 496:1-58

McClanahan TR, Graham NAJ (2005) Recovery trajectories of coral reef fish assemblages within Kenyan marine protected areas. Mar Ecol Prog Ser 294:241-248

McManus JW (1997) Tropical marine fisheries and the future of coral reefs: a brief review with emphasis on Southeast Asia. Coral Reefs 16:S121-S127

> Micheli F, Halpern BS, Botsford LW, Warner RR (2004) Trajectories and correlates of community change in no-take marine reserves. Ecol Appl 14:1709-1723 
Montero R (2009) Fisheries (Nassau grouper and species protection) regulations 2009. Book 49 of 2009. Government of Belize, Belmopan

Mumby PJ, Harborne AR (2010) Marine reserves enhance the recovery of corals on Caribbean reefs. PLoS One 5(1): e8657

Mumby PJ, Edwards AJ, Arias-Gonzalez JE, Lindeman KC and others (2004) Mangroves enhance the biomass of coral reef fish communities in the Caribbean. Nature 427: 533-536

Mumby PJ, Foster NL, Glynn Fahy EA (2005) Patch dynamics of coral reef macroalgae under chronic and acute disturbance. Coral Reefs 24:681-692

Mumby PJ, Dahlgren CP, Harborne AR, Kappel CV and others (2006) Fishing, trophic cascades, and the process of grazing on coral reefs. Science 311:98-101

Nagelkerken I, Vermonden K, Moraes OCC, Debrot AO, Nagelkerken WP (2005) Changes in coral reef communities and an associated reef fish species, Cephalopholis cruentata (Lacepede), after 30 years on Curacao (Netherlands Antilles). Hydrobiologia 549:145-154

> Newman MJH, Paredes GA, Sala E, Jackson JBC (2006) Structure of Caribbean coral reef communities across a large gradient of fish biomass. Ecol Lett 9:1216-1227

Paddack MJ, Reynolds JD, Aguilar C, Appeldoorn RS and others (2009) Recent region-wide declines in Caribbean reef fish abundance. Curr Biol 19:590-595

Paine RT (1980) Food webs: linkage, interaction strength and community infrastructure. J Anim Ecol 49:667-685

Pandolfi JM, Jackson JBC (2006) Ecological persistence interrupted in Caribbean coral reefs. Ecol Lett 9:818-826

Pandolfi JM, Bradbury RH, Sala E, Hughes TP and others (2003) Global trajectories of the long-term decline of coral reef ecosystems. Science 301:955-958

Paris CB, Cowen RK (2004) Direct evidence of a biophysical retention mechanism for coral reef fish larvae. Limnol Oceanogr 49:1964-1979

Pauly D, Christensen V, Dalsgaard J, Froese R, Torres F (1998) Fishing down marine food webs. Science 279: 860-863

Paz GE, Truly E (2007) The Nassau grouper spawning aggregation at Caye Glory, Belize: a brief history. The Nature Conservancy, Belize City

Pikitch EK, Chapman DD, Babcock EA, Shivji MS (2005) Habitat use and demographic population structure of elasmobranchs at a Caribbean atoll (Glover's Reef, Belize). Mar Ecol Prog Ser 302:187-197

Pinheiro JC, Bates DM (2000) Mixed-effects models in S and S-plus. Springer-Verlag, New York, NY

Pinnegar JK, Polunin NVC, Francour P, Badalamenti F and others (2000) Trophic cascades in benthic marine ecosystems: lessons for fisheries and protected-area management. Environ Conserv 27:179-200

Precht WF, Aronson RB, Moody RM, Kaufman L (2010) Changing patterns of microhabitat utilization by the threespot damselfish, Stegastes planifrons, on Caribbean reefs. PLoS One 5:e10835

Randall JE (1967) Food habitats of reef fishes of the West
Indies. Stud Trop Oceanogr 5:665-847

Ritchie EG, Johnson CN (2009) Predator interactions, mesopredator release and biodiversity conservation. Ecol Lett 12:982-998

$>$ Roberts CM (1995) Rapid build-up of fish biomass in a Caribbean marine reserve. Conserv Biol 9:815-826

$>$ Robertson DR (1984) Cohabitation of competing territorial damselfishes on a Caribbean coral reef. Ecology 65: 1121-1135

> Robertson DR (1996) Interspecific competition controls abundance and habitat use of territorial Caribbean damselfishes. Ecology 77:885-899

Russ GR (1985) Effects of protective management on coral reef fishes in the central Philippines. Proc 6th Int Coral Reef Symp 4:219-224

Russ GR (1991) Coral reef fisheries: effects and yields. In: Sale PF (ed) The ecology of reef fishes. Academic Press, New York, NY, p 601-724

Russ GR, Alcala AC (1998a) Natural fishing experiments in marine reserves 1983-1993: community and trophic responses. Coral Reefs 17:383-397

Russ GR, Alcala AC (1998b) Natural fishing experiments in marine reserves 1983-1993: roles of life history and fishing intensity in family responses. Coral Reefs 17:399-416

Sadovy Y (2005) Trouble on the reef: the imperative for managing vulnerable and valuable fisheries. Fish Fish 6: $167-185$

Sala E, Ballesteros E, Starr RM (2001) Rapid decline of Nassau grouper spawning aggregations in Belize: fishery management and conservation needs. Fisheries (Bethesda) 26: $23-30$

Sandin SA, Smith JE, DeMartini EE, Dinsdale EA and others (2008) Baselines and degradation of coral reefs in the northern Line Islands. PLoS One 3(2):e1548

Sponaugle S, Cowen RK (1996) Larval supply and patterns of recruitment for two Caribbean reef fishes, Stegastes partitus and Acanthurus bahianus. Mar Freshw Res 47: 433-447

Stallings CD (2008) Indirect effects of an exploited predator on recruitment of coral-reef fishes. Ecology 89: 2090-2095

Stallings CD (2009) Predator identity and recruitment of coral-reef fishes: indirect effects of fishing. Mar Ecol Prog Ser 383:251-259

Steneck RS (1998) Human influences on coastal ecosystems: Does overfishing create trophic cascades? Trends Ecol Evol 13:429-430

Steneck RS, Paris CB, Arnold SN, Ablan-Lagman MC and others (2009) Thinking and managing outside the box: coalescing connectivity networks to build region-wide resilience in coral reef ecosystems. Coral Reefs 28: 367-378

> Williams AH (1978) Ecology of threespot damselfish: social organization, age structure, and population stability. J Exp Mar Biol Ecol 34:197-213

> Williams AH (1981) An analysis of competitive interactions in a patchy back-reef environment. Ecology 62: 1107-1120

Submitted: August 2, 2011; Accepted: October 14, 2011 Proofs received from author(s): January 10, 2012
Editorial responsibility: Janet Ley, St. Petersburg, Florida, USA 